\title{
Effects of Gamma-Irradiation on the Sterilization of Primordial Germ Cells in Quail
}

\author{
Kyung Je Park, Tae Min Kim, Hyung Chul Lee, Hyun-Jun Jang, Gwonhwa Song and Jae Yong Han ${ }^{\dagger}$ \\ WCU Biomodulation Major, Department of Agricultural Biotechnology, Seoul National University, Seoul 151-921, Korea
}

\section{메추리 원시생식세포 감소를 위한 감마선 조사의 효과}

\author{
박경제·김태민 · 이형철 · 장현준 · 송권화 · 한재용 ${ }^{\dagger}$ \\ 서울대학교 농생명공학부 $\mathrm{WCU}$ 바이오모듈레이션 전공
}

\begin{abstract}
Quail is a very useful animal model for studying vertebrate development because of its small body size and unique reproductive traits. This species is also ideal model for producing germline chimeras via transferring exogenous primordial germ cells (PGCs) into the recipient embryo. To increase the contribution efficiency of donor PGCs into recipients' tissues, decreasing the population of endogenous PGCs has been rate-limiting factor. We therefore conducted this study to investigate if gamma $(\gamma)$ irradiation depletes endogenous PGCs in developing quail embryo. Firstly, freshly laid stage X quail embryos were irradiated with various output of $\gamma$-irradiation and its teratogenic effect on the embryo was evaluated. Although a dose-dependent increase in the number of embryo showing malformation was found as the output increased $(0,250,500,750$, and 1,000 rads), only a maximum of $10.1 \%$ of embryos were abnormal in 1,000 rads. Immunocytochemical analysis using the QCR1 antibody, which is specific marker for quail PGCs, was conducted to analyze the effect of sterilization. As results, $\gamma$-rays at a dose-rate of $500 \mathrm{rads} / 73 \mathrm{sec}$ onto undeveloped stage $\mathrm{X}$ embryo significantly reduced the number of germ cells to an average of $75.55 \%$ and $82.03 \%$ in male and female embryos, respectively. We conclude that $\gamma$-ray selectively targets PGCs while affects minimally to the somatic development in quail embryo. Our results will not only provide important data for germline chimera production but can be used for analyzing the effect of ionized rays on the differentiating germ cells in various stages during animal development.
\end{abstract}

(Key words : chimeras, primordial germ cells (PGCs), gamma $(\gamma)$-irradiation, stage $\mathrm{X}$ quail embryos)

\section{INTRODUCTION}

Birds are an exceptional model species for conducting various experimental purposes in basic and biotechnological researches. Quail (Coturnix coturnix japonica) is a unique bird model because it is easy to handle and reproduce rapidly compared to other domestic birds (Padgett and Ivey, 1959). Germ cells in birds can contribute to developing avian model because they can be used for producing germline chimeras (Tajima et al., 1993). Sterilization of germ cells in recipient embryos are an important step for increasing the chimerism, and thus continuous efforts have been made. A surgical method that partially removing the central area of blastodermal tissue was introduced by Kagami et al. (1997), which resulted in the production of germline chimera with low efficiency. Moreover, this method is laborious and the survivability is low. An alkylating agent busulfan (1,4-butanediol dimethanesulfonate), has also been developed for the same purpose (Song et al., 2005); however, it interfered with the proliferation of donor germ cells (Song et al., 2005). Other methods utilized X-rays or ultraviolet light, however these have not been feasible because of high mortality and low efficiency (Aigegil and Simkiss, 1991).

Gamma $(\gamma)$-irradiation was initially developed for medical purposes, as it can induce selective apoptosis. In birds, Carsience et al. (1993) first reported the potential of $\gamma$-irradiation of 500 to 700 rads using a ${ }^{60} \mathrm{Co}$ source to induce partial sterilization of germ cells in recipient embryo without affecting hatchability, and a comparable effect was shown by irradiating 400 to 500 rads of ${ }^{137} \mathrm{Cs}$ source (Thoraval et al., 1994). Although the

\footnotetext{
† To whom correspondence should be addressed : jaehan@snu.ac.kr
} 
initial successful use of $\gamma$-ray has long been attempted to prepare sterilized recipient embryo during germline chimera production in chicken, no data on the effectiveness of this technique was reported in quail. Therefore, in this study, we examined if the number of PGCs in recipient embryo can be decreased after $\gamma$-ray irradiation in quail.

\section{MATERIALS AND METHODS}

\section{Experimental Animals and Animal Care}

The quail of the wild-type plumage (WP: $d^{+} / d^{+}$) were used in this experiment. The care and experimental use of WP quails were approved by the Institute of Laboratory Animal Resources, Seoul National University (SNU-070823-5). The WP quails were maintained in a standard management program at the University Animal Farm, Seoul National University, Korea. The procedures for animal management, reproduction, and embryo manipulation followed standard operating protocols used in our laboratory.

\section{Experimental Design}

In the first experiment, stages $\mathrm{X}$ embryos of WP quail were exposed to gamma $(\gamma)$-ray irradiation at various irradiation doses $(0,200,500,750$, and 1,000 rads) and then the hatching rate was monitored. In the second experiment, stage $\mathrm{X}$ embryos were incubated for two days and blood was drawn to discriminate the sex by amplifying W-specific locus. After further incubation for three days, the gonadal cells retrieved from 5.0-day-old (stage 28) embryos were monitored by staining with antibody against QCR1 as described previously (Aoyama et al., 1992; Kim et al., 2005). The numbers of gonadal cells and PGCs were counted by our standard procedure (Kim et al., 2005). Briefly, the gonadal tissue was dissociated by gentle pipetting in $0.05 \%(\mathrm{v} / \mathrm{v})$ trypsin solution supplemented with $0.53 \mathrm{mM}$ EDTA for $10 \mathrm{~min}$, and gonadal cells, including gonadal PGCs (gPGCs) and stroma cells, were retrieved by centrifugation at $200 \times \mathrm{g}$ for $5 \mathrm{~min}$. After culture for 24 hours, cells were fixed in $1 \%(\mathrm{v} / \mathrm{w})$ glutaraldehyde for $5 \mathrm{~min}$. After washed twice in PBS, the fixed cells were stained with the mouse monoclonal IgG antibody QCR1 (1:200 dilution in PBS), which was specific for quail gPGCs, and with a Universal LSAB Peroxidase kit (Dako Cytomation, Carpinteria, CA). The number of immunoreactive gPGCs was counted with an inverted microscope.

\section{Gamma-Irradiation}

The eggs were placed with the flat side upward on a canister installed in the chamber of an irradiation apparatus (GC-3,000 ELAN, MDS Nordion, Germany). Embryos at stage X were irradiated at doses of $0,200,500,750$, and 1,000 rads for $0,39,73$, 110 and 149 seconds of $\gamma$-ray for examining the teratogenic effect and hatching rate. For sterilizing of PGCs, embryos were irradiated with 500 rads for 73 seconds.

\section{Sex Determination of Irradiated Embryos}

The sex of each donor embryo was determined via PCR analysis using a nonrepetitive DNA sequence on the $\mathrm{W}$ chromosome (5'- CTA TGC CTA CCA CAT TCC TAT TTG C-3' and 5'-AGC TGG ACT TCA GAC CAT CTT CT-3') (Ogawa et al., 1997). Embryonic blood cells $(1 \mu \mathrm{L})$ were collected once from the dorsal aorta of 2-day-old embryos through the egg shell window. Each blood sample was diluted 100-fold in PBS and then boiled for $5 \mathrm{~min}$ at $99{ }^{\circ} \mathrm{C}$ before being used for PCR. After the collection, the window of the egg was sealed with parafilm and the egg was subsequently incubated before being analyzed or hatched at $37.5{ }^{\circ} \mathrm{C}$ in an air atmosphere with $60 \%$ humidity.

\section{Statistical Analysis}

The values of each experimental parameter were subjected to analysis of variance (ANOVA) using the general linear model (PROC-GLM) in the SAS program (SAS Institute, Cary, $\mathrm{NC}$, USA). When the model effect was significant, the values for each treatment group were subsequently compared by the least-squares method. Differences were considered statistically significant at $P<0.05$.

\section{RESULTS}

We firstly examined the proportion of embryos that shows abnormality after being exposed to various dosage of $\gamma$-irradiation, and found that the number of abnormal embryos increased as the output increased (Table 1). Secondly, the hatchability of irradiated embryos was examined. A significant de- 
crease was noted in embryos irradiated with 500 rads compared with non-irradiated control (Table 2, $81.48 \%$ vs. $59.25 \%$ in non-irradiated and irradiated embryos, respectively). Thirdly, the effect of irradiation with 500 rads on the number of PGCs were monitored and resulted that irradiation significantly reduced the proportion of PGCs in total gonadal cells (Fig. 1 and 2) ( $107.75 \pm 3.96$ vs. $80.30 \pm 4.34$ in control and irradiated male, respectively; and $99.56 \pm 3.22$ vs. $81.67 \pm 3.72$ in control and irradiated female, respectively).

Table 1. Teratogenic effects of gamma-irradiation on quail embryos

\begin{tabular}{ccc}
\hline \hline Rads & $\begin{array}{c}\text { No. of embryos } \\
\text { irradiated }\end{array}$ & $\begin{array}{c}\text { Number of embryos } \\
\text { with abnormality }{ }^{\mathrm{a}}(\%)^{\mathrm{b}}\end{array}$ \\
\hline 0 & 88 & $0(0)$ \\
250 & 81 & $1(1.2)$ \\
500 & 82 & $2(2.4)$ \\
750 & 74 & $4(5.4)$ \\
1000 & 69 & $7(10.1)$ \\
\hline
\end{tabular}

${ }^{\mathrm{a}}$ Stage 28 embryos were screened.

${ }^{b}$ Percentage of the number of embryos that were irradiated.

Table 2. Effect of gamma-irradiation on the hatching ratio of stage $\mathrm{X}$ quail embryos

\begin{tabular}{ccc}
\hline \hline \multirow{2}{*}{$\begin{array}{c}\text { Irradiation dose } \\
\text { (rads) }\end{array}$} & \multicolumn{2}{c}{ No. of embryos } \\
\cline { 2 - 3 } & Irradiated & Hatched (\%) \\
\hline 0 & 270 & $220(81.48)^{\mathrm{a}}$ \\
500 & 270 & $160(59.25)^{\mathrm{b}}$ \\
\hline
\end{tabular}

${ }^{\mathrm{a}, \mathrm{b}} \mathrm{P}=0.0035$.
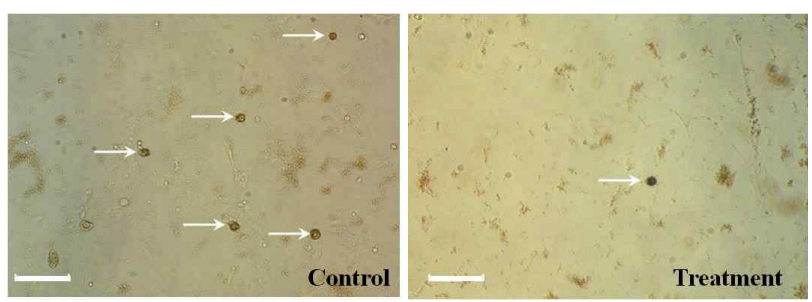

Fig. 1. Immunological detection of primordial germ cells of stage 28 embryos that were gamma-irradiated at stage $\mathrm{X}$. QCR1-stained cells (arrows) were decreased in irradiated embryos (right). Left is a non-irradiated control. Scale bar $=100 \mu \mathrm{m}$.

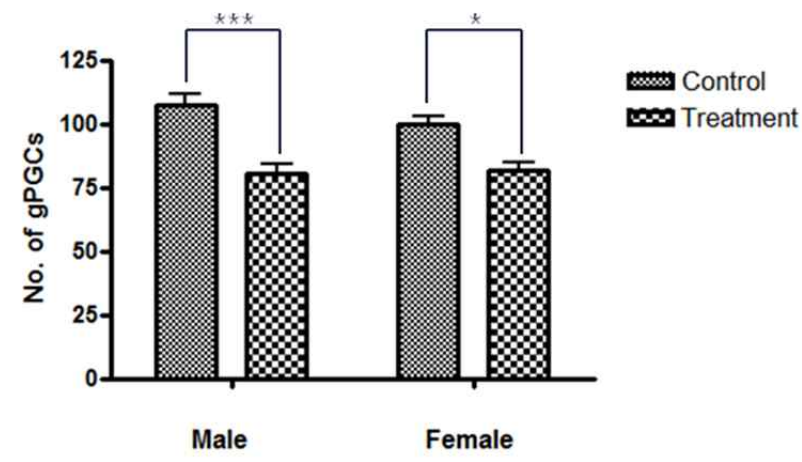

Fig. 2. Effects of gamma-irradiation on the number of primordial germ cells of both sexes of quail embryos. Stage $\mathrm{X}$ embryos were exposed to 500 rads of gamma-ray and the number of PGCs were analyzed at stage $28\left({ }^{* * *} P=0.0015,{ }^{*} P=\right.$ 0.002). Data are from three replicates.

\section{DISCUSSION}

Attempts have been continuously made to deplete the number of recipients' endogenous germ cells, and gamma $(\gamma)$-irradiation has been recognized as the most efficient method for depleting germ cells in the recipient embryos (van de Lavoir et al., 2006; Thoraval et al., 1994; Carsience et al., 1993). In the present study, we compared the number of PGCs after $\gamma$-irradiation with those of untreated control, and found that $\gamma$-ray exerted its role onto the germ cells. More embryos with developmental anomaly were found as the output increased, however, such effect was not significant as that in chicken (Table 1 and unpublished data). Although we cannot clearly explain what caused such difference, it may be assumed that the selectivity of irradiation upon germ cells is somewhat higher in quail than that in chicken (Lim et al., 2005). However, the sterilization effect on the PGCs was below expected, although immunological staining of gamma-irradiated quail gonadal cells demonstrated the effect of gamma-ray on reducing the number of quail PGCs (Fig. 2). The present gamma-irradiation exposure time (73 seconds) was based on work from chicken (unpublished), we therefore assume that exposure duration should be further optimized for extending the usability of gamma-irradiation onto quail embryo.

The hatching rate of gamma-irradiated embryos was significantly lower than untreated control. Although it is obvious that this should be overcome by implementing other ideal steriliza- 
tion method or further optimization, it does not seem to exclude the workability of this process because near $60 \%$ of embryos can hatch after gamma-irradiation (Table 2).

Further studies on the efficiency of germline transmission after testcross with wild-type quails should be conducted to functionally assess the feasibility of this method in quail. However, our data on the rate of PGC depletion, teratogenic analysis and the hatchability will offer various important aspects for implementing this technique. In conclusion, we showed that gammairradiation on stage $\mathrm{X}$ embryos significantly reduces the endogenous germ cells in quail while maintaining reasonable hatching rate. This technique will help to produce quail germline chimeras for transgenic production.

\section{적 요}

조류의 원시생식세포는 수용체 배자로의 주입을 통해서 생식선 카이메라 생산을 가능하게 하기 때문에 유전자 도입 에 매우 효율적인 도구이다. 특히, 메추리는 성성숙이 빠르 며 산란능력이 뛰어 나기 때문에 형질전환 조류 생산과 유 전자 기능 연구에 매우 적합하다. 형질전환 조류 생산 효율 을 높이기 위해서는 수용체 배자 내의 원시생식세포의 수를 줄이는 것이 필수적인 요소이지만, 아직까지 메추리에서 이 러한 시도를 했다는 보고는 없다. 본 연구는 감마선 조사가 수용체 내의 원시생식세포의 수를 감소시킬 수 있는지 알아 보았다. 먼저 $0,250,500,750,1,000 \mathrm{rads}$ 강도의 감마선을 갓 산란된 메추리알에 조사 후 5일령 배자에서 기형 발생빈도 를 측정하였고, 0 과 $500 \mathrm{rads}$ 에서 17 일째 부화율을 검정하였 다. 그리고 $500 \mathrm{rad}$ 의 감마선을 산란된 알에 73 초간 조사 후 5 일간 배양시킨 뒤 원시생식세포의 수를 측정하였다. 그 결과, $1 \times 10^{4}$ 개의 세포 당 원시생식세포의 수는 수컷은 $107.75 \pm$ 3.96 에서 $80.30 \pm 4.34$ 로, 암컷에서 $99.56 \pm 3.22$ 에서 $81.67 \pm 3.72$ 로 원시생식세포수가 감소되었다. 이상의 연구 결과는 감마 선 조사가 수용체 배자내의 원시생식세포를 감소시킬 수 있 고, 이를 형질 전환 기술에 접목시켜서 생식선 카이메라 효 율을 높일 수 있는 가능성을 보여 주고 있다.

(색인어 : 원시생식세포, 카이메라, 감마선 조사)

\section{ACKNOWLEDGMENTS}

This research was supported by grant from Basic Science
Research Program (KRF-2006-311-F00087) and WCU program (R31-10056) through the National Research Foundation of Korea funded by the Ministry of Education, Science and Technology. We thank Dr. H. Aoyama (Hiroshima University) for providing the QCR1 antibody and Dr. T. Ono (Shinshu University) for scientific comments. Gamma-irradiation was conducted at the National Center for Inter-University Research Facilities, Seoul National University.

\section{LITERATURES CITED}

Aigegil V, Simkiss K 1991 Sterilizing embryos for transgenic chimeras. Br Poult Sci 32:427-438.

Aoyama H, Asamoto K, Nojyo Y, Kinutani M 1992 Monoclonal antibodies specific to quail embryo tissues: their epitopes in the developing quail embryo and their application to identification of quail cells in quail-chick chimeras. J Histochem Cytochem 40:1769-1777.

Carsience RS, Clark ME, Verrinder Gibbins AM, Etches RJ 1993 Germline chimeric chickens from dispersed donor blastodermal cells and compromised recipient embryos. Development 117:669-675.

Kagami H, Tagami T, Matsubara Y, Harumi T, Hanada H, Maruyama K, Sakurai M, Kuwana T, Naito M 1997 The developmental origin of primordial germ cells and the transmission of the donor-derived gametes in mixed-sex germline chimeras to the offspring in the chicken. Mol Reprod Dev 48: 501-510.

Kim MA, Park TS, Kim JN, Park HJ, Lee YM, Ono T, Lim JM, Han JY 2005 Production of quail (Coturnix japonica) germline chimeras by transfer of gonadal primordial germ cells into recipient embryos. Theriogenology 63:774-782.

Lim JM, Kwon HM, Kim DK, Kim JN, Park TS, Ono T, Han JY 2006 Selective decrease of chick embryonic primordial germ cells in vivo and in vitro by soft $\mathrm{X}$-ray irradiation. Anim Reprod Sci 95:67-74.

Ogawa A, Solovei I, Hutchison N, Saitoh Y, Ikeda JE, Macgregor H, Mizuno S 1997 Molecular characterization and cytological mapping of a nonrepetitive DNA sequence region from the $\mathrm{W}$ chromosome of chicken and its use as a universal probe for sexing carinatae birds. Chromosome Res 5: 
93-101.

Padgett CA, Ivey WD 1959 Coturnix quail as a laboratory research animal. Science 129:267-268.

Song Y, D'Costa S, Pardue SL, Petitte JN 2005 Production of germline chimeric chickens following the administration of a busulfan emulsion. Mol Reprod Dev 70:438-444.

Tajima A, Naito M, Yasuda Y, Kuwana T 1993 Production of germ line chimera by transfer of primordial germ cells in the domestic chicken (Gallus domesticus). Theriogenology 40: 509-519.
Thoraval P, Lasserre F, Coudert F, Dambrine G 1994 Somatic and germline chimeras obtained from Brown and White Leghorns by transfer of early blastodermal cells. Poultry Sci 73: 1897-1905.

van de Lavoir MC, Diamond JH, Leighton PA, Mather-Love C, Heyer BS, Bradshaw R, Kerchner A, Hooi LT, Gessaro TM, Swanberg SE, Delany ME, Etches RJ 2006. Germline transmission of genetically modified primordial germ cells. Nature 441:766-769.

(접수: 2010. 4. 17, 수정: 2010. 5. 25, 채택: 2010. 5. 26) 